\title{
The Snake and the Mongoose: The Emergence of Identity in Early Indian Religion, written by Nathan McGovern
}

\author{
CLAIRE MAES \\ The University of Texas at Austin, United States
}

This book revisits the religious landscape of ancient North India in terms of its origins and identity formations. It offers a new model to study the emergence of Brahmanism, Buddhism, and Jainism that effectively moves away from a binary model of strife between Brahmanical and non-Brahmanical traditions. McGovern argues that modern scholarship has unjustly projected the image of the "snake and the mongoose" onto the development of ancient Indian religions. Such an image, he writes, incorrectly assumes an intrinsic dichotomy and hostility between the Brahmans and the śramana movements in ancient India (3-5). McGovern argues instead that we understand Brahmanism, Buddhism, and Jainism "as having emerged out of a period of dialectical identity formation. In particular, [as] ... having emerged out of a period of contestation over the category Brahman, which all of them sought to claim" (4). To make this claim, McGovern examines key concepts and terms central to the articulation of religious identity across a critical selection of primary sources belonging to the Brahmanical, Buddhist, and Jain traditions, as well as Greek writings and the Aśokan edicts.

The reason why scholars of ancient Indian religions have repeatedly fallen back on the binary model of Brahmanical and non-Brahmanical traditions is explained in chapter 1. Examining the history of Western Buddhology, McGovern shows how this model resulted, in part, from a "historical accident" (85) linked to the scholarship of Eugène Burnouf (18011852). True to the scientific spirit of his time, the French Indologist engaged with the question of which came first: Brahmanism or Buddhism. While correctly establishing the chronological priority of Brahmanism based, however, as McGovern shows, on flawed chronological assumptions about the texts, Burnouf's work set the course for the academic study of Buddhism. As McGovern argues, Burnouf placed the origins of Buddhism not just in an Indian context, but in a thoroughly "Brahmanical Indian context" (8). European scholars elaborated on Burnouf's findings, McGovern writes, by superimposing a "protestant narrative" on the origins of Buddhism, turning the Buddha into a reformer akin to Martin Luther (9). McGovern argues strongly for abandoning these long-standing tropes in the study of Indian Buddhism. Instead, he argues that we take earnestly the insight, first articulated by T. W. Rhys Davids (1843-1922) and more recently by Johannes Bronkhorst, "that ancient India was far less 'Brahmanical' than Brahmanical texts make it appear" (13). McGovern proposes a study 
of the formation of religious identities in ancient India that does not rest on the "methodological error of assuming that Brahmanism was metahistorically prior to Buddhism and Jainism" (85), and that departs from a non-binary model that takes all articulations of Brahmanhood, including Buddhist and Jain ones, seriously.

Chapter 2 discusses the available sources and the challenges these pose in reconstructing the early Indian religious landscape. McGovern shows that during the Mauryan period "a conception of the śramana and Brahman as mutually opposed already existed" (61). He further argues that modern scholars have unjustly projected this back to the beginning of the Buddhist and Jain communities, resulting in a "model of Buddhism and Jainism as having arisen in the context of a fundamental conflict between two opposed groups" (61). He begins deconstructing this model in chapter 3 , where he shows that the compound śramanabrähmana does not entail an inherent opposition between the two categories as has often been assumed (67-84).

In chapter 4, McGovern proceeds to a contextual reading of the word Brahman within the earliest strata of the Buddhist and Jain texts, which he identifies as the Atthaka Vagga and the core verses of the Pārāyaṇa Vagga for Buddhists and the first book of both the Āyāraniga and the Süyagadamga Sutta for Jains (87). He shows how this literature is "characterized by a pervasive trope of referring to the ideal [Buddhist or Jain] person-either in the abstract or specifically to the founder of the monastic order himself-as a Brahman" (98). McGovern seeks to interpret these Brahman references at face value, without reverting to the well-known academic language of "adoption" and "borrowing" or theories of "marketing" and "polemic strategies" (85-86). Put simply, if the Buddha is called a Brahman, he should be considered a Brahman. McGovern argues that the reason why a theory of marketing, for instance, is inadequate for understanding the early Buddhist and Jain uses of the word Brahman is because they are not, unlike in later canonical literature, rhetorically contrasted to Vedic Brahmans. He demonstrates that the early Buddhist and Jain claims of Brahmanhood were based "on the practice of celibate studentship known as brahmacarya" (129). Questioning what these claims mean for the negotiation of religious identities, McGovern concludes that "the earliest identity we find articulated by the Buddhists and Jains is a self-consciously Brahmanical identity" (99). In other words, for the early Buddhists and Jains, "Brahman was not primarily a category of otherness, but of selfhood" (129), whereas "the word śramana [w] as a category of otherness" (130). He sees this in part as corroborated by the fact that Buddhists, according to him, associated more closely with the "Brahmanical" jațilas than with the "śramanic" Jains or Âjīvakas and, on the other hand, viewed householders as an "absolute other" since they rejected the "Brahmanical" values of celibacy and renunciation (87).

To further map the different articulations of Brahmanhood in ancient India, chapter 5 explores the concept in the Dharma Sūtras. It gives special attention to the Dharma Sūtra of Āpastamba that defines Brahmanhood in terms of the householder lifestyle and that introduces, for the first time, a clear articulation of both the varna system and the āśrama system. McGovern proposes to call those who support a vision of Brahmanhood as rooted in householdership "the proponents of a Neo-Brahmanism, in recognition of the fact that while claiming to be the heirs of an ancient tradition, they were in fact reinventing that tradition in the fashion of any number of so-called conservative, but more aptly called reactionary, groups throughout history" (133). Drawing attention to the fact that the texts intertwine the normative and the descriptive, McGovern argues to read the Dharma Sütras not as "internal 'Brahmanical' documents" but as "polemical texts" engaging with other competing understandings of Brah- 
manhood in ancient India $(136,160)$. In this spirit, he suggests viewing the varna system as "a polemical and rhetorical strategy that served a particular ideological agenda" (137). Similarly, the āśrama system should be considered a "theoretical taxonomy composed by householder Brahmans to describe in detail actual social practice, and then reject all lifestyles that did not conform to their own" (137). For McGovern, then, both the varna and áśrama systems "worked in tandem to advance the householder supremacist agenda by describing society first as it should be, and then as it unfortunately actually was" (137).

The final two chapters explain the emergence of the "snake and the mongoose" trope in ancient India and the success of Neo-Brahmans in appropriating the term Brahman. He convincingly shows how the rhetoric of Brahmanhood changed over time (166) and argues that the early Brahman references referring straightforwardly to either the Buddhist ideal, the Buddha himself, or to other Awakened Buddhists came to be transformed into "a polemic against those who claimed Brahmanhood on the basis of birth" (192). The Buddhist texts he analyses are the Mahānidessa, being the earliest canonical commentary on the Atthaka; a Chinese translation of a version of the Atțhaka (the Yìzújing), which embeds and thus also interprets the Atthaka verses within prose frame narratives (166); and the narratives framing the older verses of the Pārāyana (191). To show how the proponents of Neo-Brahmanism came to successfully arrogate the previously contested category of Brahman, McGovern examines a genre of sūtras he calls "encounter dialogs" (196-7) in the Buddhist Samyutta and Digha Nikāyas (198-207) and also, to a lesser degree, in the Jain canon (207-210). As McGovern shows, these sūtras mock and publically humiliate Neo-Brahmans. They offer "rhetorical punches" that both ridicule the Neo-Brahmanical visions of society and demonstrate the inconsistencies and absurdities of their claims. Yet, as McGovern writes, "the encounter dialog genre ultimately undermined its own purpose" insofar as there is "no such thing as bad publicity" (211). In refuting the claims of Neo-Brahmans, the encounter dialogs "replicated and amplified the very ideas it was arguing against," resulting in "free press" for the proponents of Neo-Brahmanism (211). According to McGovern, if Buddhists and Jains ultimately ceded the category Brahman to the proponents of Neo-Brahmanism, it is not because the claims of NeoBrahmans became more truthful or reflective of social reality, far from it; rather, just like witty politicians, Neo-Brahmans "framed the debate" and "relentlessly stayed on message" (210-216).

While the major part of The Snake and the Mongoose focuses "on the methodological issues surrounding the relationship between the categories śramana and Brahman," McGovern concludes with, in his words, "a speculative account" of what the historical process might have actually looked like (219). In this account, he sketches North India in the fifth century BCE as being characterized by a field of competing religious teachers who, in response to increasing urbanization, were innovating the older Vedic teachings and practices to varying degrees. Within this field, he considers early Buddhists and Jains to be avant-gardists, embracing progressive innovations while maintaining some continuity with the traditions preserved in the Vedas. The proponents of Neo-Brahmanism who defined Brahmanhood in terms of the householder lifestyle, on the other hand, were reactionary (219-222).

Whether or not one will agree with the conclusions of The Snake and the Mongoose, it is a solid piece of scholarship that, at the very least, will make one rethink what one thinks one knows about the category "Brahman." While some arguments will appear controversial to the reader, they are worthwhile to engage with critically. The Snake and the Mongoose shows the importance of contextually analyzing identity categories both within and across religious tra- 
ditions. It also demonstrates the fallacy of anachronistic readings and the methodological need to not "simply situate Buddhism and Jainism against a Brahmanical context," but to recognize that "these traditions brought each other into existence" (222). At the same time, since McGovern mainly examines the term Brahman and the category Brahmanhood, it raises the question which dialectic would emerge if other significant identity categories were investigated, such as muni, bhikșu, and tirthika. While scholars today readily accept the importance of studying the formation of religious identities in non-essential terms, they have yet to find a model for examining the emergence of Indian religions that did not revert to the essentializing image of "the snake and the mongoose." In his study of the religions of ancient India, McGovern convincingly moves away from the binary model of Brahmanical and non-Brahmanical traditions and shows how Brahmanism, Buddhism, and Jainism are best understood as complex and dynamic groups changing in dialectical relation to one another.

The Snake and the Mongoose by Nathan McGovern contributes significantly to our understanding of early South Asian religious history. Given the transparency of the argumentation, the clarity of the methodology, as well as the engaging discussions of both the primary sources and contemporary scholarship, it will be of interest to both scholars and students of ancient India, South Asian religions, and religious studies in general.

Nathan McGovern (2019). The Snake and the Mongoose: The Emergence of Identity in Early Indian Religion. Oxford University Press. 